\title{
Diversity and Characterization of Mushrooms from District Haripur, KPK, Pakistan
}

\author{
Saira Bibi*, Muhammad Fiaz khan and Aqsa Rehman \\ Department of Zoology, Pakistan
}

*Corresponding author: Saira Bibi, Department of Zoology, Pakistan

\begin{abstract}
ARTICLE INFO
Received: 慧 May 23, 2019

Published: May 31, 2019

Citation: Saira Bibi, Muhammad Fiaz khan, Aqsa Rehman. EDiversity and Characterization of Mushrooms from District Haripur, KPK, Pakistan. Biomed J Sci \& Tech Res 18(3)-2019. BJSTR. MS.ID.003168.
\end{abstract}

Keywords: Mushrooms; Diversity; District Haripur

\begin{abstract}
During the present study total of 19 families including 40 species were recorded enlisted in Table 1. The highest number of wild edible mushroom species recorded was of the Pleurotaceae family (Pleurotus pulmonarius, P. giganteus, P. tuberregium, P. djamor var. djamor, and P. djamor var. roseus). The second highest number of species recorded was from the Polyporaceae family (Lentinus sajor-caju, L. squarrosulus, and Panus lecomtei). All three species are white rot fungi with distant or crowded lamellae (as in Agaricales). Auriculariaceae family also comprises three species (Auricularia polythrica, Auricularia auricular-judae and Auricularia sp. 1) which are all edible. Among 40 wild edible mushrooms, only five were reported for medicinal uses. These mushrooms are Pleurotus tuber-regium, Auricularia sp., Xylaria sp., Lignosus sp. and Schizophyllum commune. The rare species of Termitomyces eurhizae (Lyophyllaceae) and Hygrocybe miniata (Hygrophoraceae) from lowland forests was found in this study. It is the first reported study from District Haripur. Local people were having very little knowledge on mushrooms. This will be helpful for the local community and researchers.
\end{abstract}

\section{Introduction}

For their value as nutritional Mushrooms are highly prized [1], and medicinal foods for their use in cosmetics [2], In every field including in agriculture, industry, medicine, food industry, textiles, and bioremediation Fungi play an important role [3]. Into three different forms yeast, moulds and macrofungi or mushrooms Fungi can be broadly classified or mushrooms. Large, conspicuous spore bearing structures and have fleshy, tough umbrella like sporophores that bear holobasidia on the surface of gills or lamellae that hang down from the cap belonging to basidiomycetes and ascomycetes are the Macrofungi [4]. Depending on the composition of tree species and other substrates Mushrooms are found in varied types of habitats. Due to favourable climate and abundance of flora during that time Mushrooms are abundant in spring to autumn while less distributed in dry and hot seasons [5]. By having the great economic importance they serve as the essential part of the human diet and are used as both medicine and food for centuries, mushrooms are rich in pharmacological properties, easy to cultivate, requires low resources and area, and can be grown all over the world [6]. most important organisms on Earth, both in terms of a high species richness and their functional roles in aquatic and terrestrial ecosystems [7]. for species identification there is need of a wide taxonomical knowledge and a high field sampling effort [8].

The knowledge of the macrofungal component represents a useful tool for the establishment of priorities for sites of conservation and an indicator of forest worries [9]. In the ethology of acute exogenous intoxication Poisonings with mushrooms have an important position and are one of the main reasons for hospitalization [10]. Causing organ failure with potentially fatal outcome Death cap (Amanita phalloides) poisoning is a serious medical condition [11]. After mushrooms ingestion It is a toxic mushroom responsible for the majority of deaths occurring [12]. All deaths due to mushroom poisoning It is the cause of 9095\%. Rather rare Mushroom poisonings with fly agaric (Amanita muscaria) and panther cap (Amanita pantherina). Due to the short growing season and a high demand to wild mushrooms a large number of edible wild mush rooms are seasonally harvested, as an example up to 700 species of wild mushrooms are known to be edible and are utilized by local indigenous people as both a source of food and income in china. Due to the uniqueness to the area 
many mushrooms are would drive up the market price of these species, and in turn encourage over harvesting. For the local people the importance and their availability is important there they think mushrooms priceless so in order to document the diversity of these mushrooms both in terms of edible and non-edibles this study is conducted in district Haripur.

\section{Material and Methods}

\section{Methodology}

Study Area: Study area was conducted in the district Haripur KPk Pakistan. Haripur is the main city of the Haripur District in Hazara, Khyber Pakhtunkhwa in Pakistan, with Swabi and Buner to the west, some $65 \mathrm{~km}$ north of Islamabad and $35 \mathrm{~km}$ south of
Abbottabad. It is in a hilly plain area at an altitude of $520 \mathrm{~m}$. Having the $33.9946^{\circ} \mathrm{N}, 72.9106^{\circ} \mathrm{E}$. With the pleasant weather and hilly areas with grasses and pine trees (Figure 1).

\section{Sampling and Data Collection}

Investigation of mushrooms were carried out during the whole year from January 2018 to December 2018 Sampling was performed by using 20 circular (4-m radius) plots (60 in total) selected in each study site along line-transects and for macrofungi following a standardized sampling method. Each plot was $20 \mathrm{~m}$ away from the next one. For each site total sample area was approximately 1,000 $\mathrm{m}^{2}$. Species identification was performed by analyzing the macroand microscopically characteristics of the collected specimens and the relevant literature.

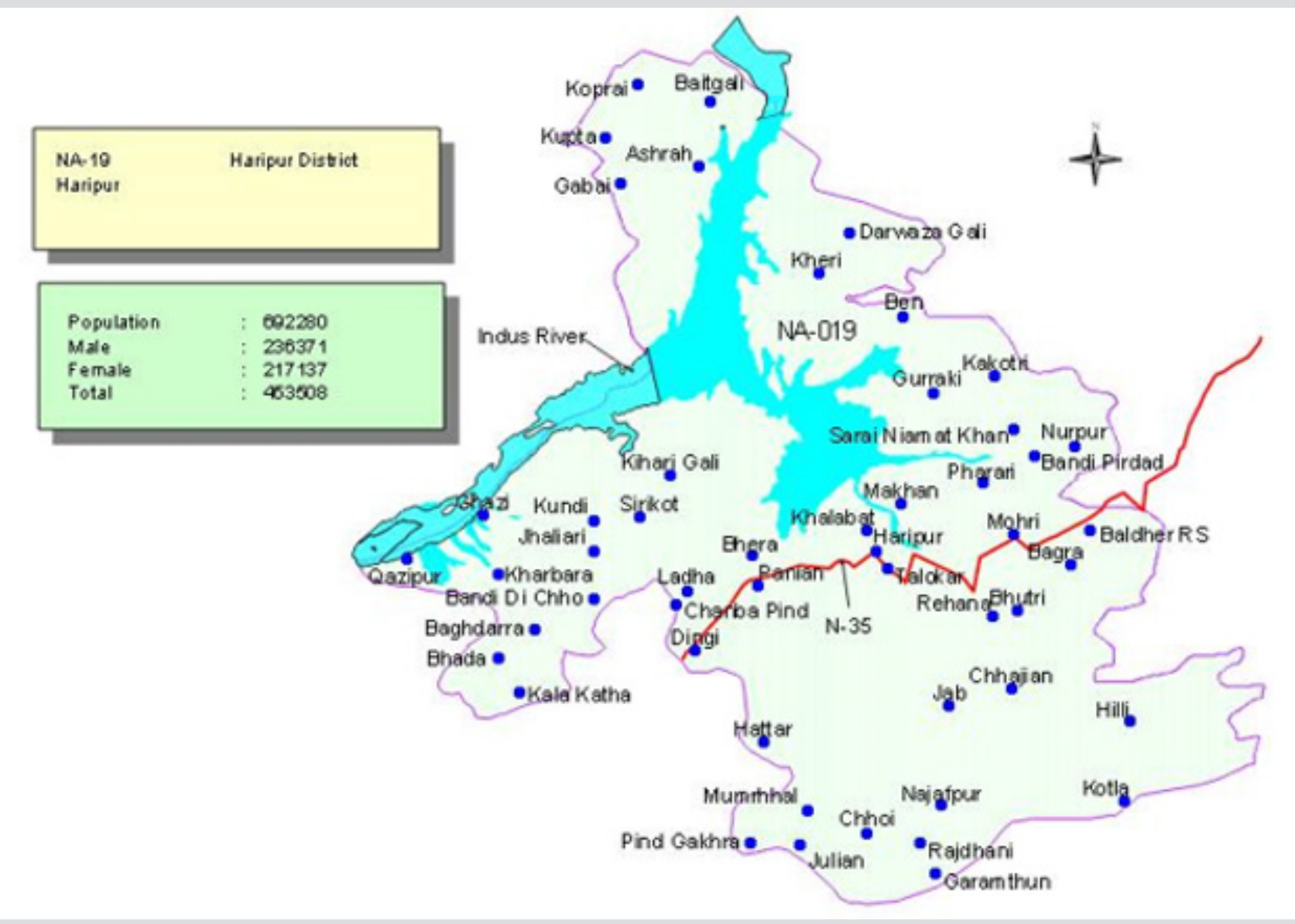

Figure 1: Map of district Haripur (Google source).

\section{Results}

During the present study total of 19 families including 40 species were recorded enlisted in Table 1. The highest number of wild edible mushroom species recorded was of the Pleurotaceae family (Pleurotus pulmonarius, P. giganteus, P. tuberregium, $P$. djamor var. djamor, and P. djamor var. roseus). The second highest number of species recorded was from the Polyporaceae family (Lentinus sajor-caju, L. squarrosulus, and Panus lecomtei). All three species are white rot fungi with distant or crowded lamellae (as in
Agaricales). Auriculariaceae family also comprises three species (Auricularia polythrica, Auricularia auricular-judae and Auricularia sp. 1) which are all edible. Among 40 wild edible mushrooms, only five were reported for medicinal uses. These mushrooms are Pleurotus tuber-regium, Auricularia sp., Xylaria sp., Lignosus sp. And Schizophyllum commune. The rare species of Termitomyces eurhizae (Lyophyllaceae) and Hygrocybe miniata (Hygrophoraceae) from lowland forests was found in this study. An edible, Calostoma insignis (Calostomataceae) and poisonous Agaricus pracelaresquamosus were also recorded (Figure 2). 
Table 1: Recorded species of mushrooms from district Haripur.

\begin{tabular}{|c|c|c|c|c|}
\hline Family & Scientific name & Local name & Habitat & status of $\mathrm{E} / \mathrm{NE}$ \\
\hline \multirow{2}{*}{ Gomphaceae } & \multirow{2}{*}{ Cantharellus floccsus } & shaggy scaly & shady areas & \multirow{2}{*}{ non edible } \\
\hline & & califlower mushroom & shady & \\
\hline Sparassidaceae & Conocyba crispa & places & & edible \\
\hline \multirow{3}{*}{ Morchellaceae } & \multirow{2}{*}{ M. conica } & guchhi & shady areas & edible \\
\hline & & chawara & shady areas & edible \\
\hline & M. anqusticipt & mushroom & & edible \\
\hline \multirow{7}{*}{ Suillaceae } & Boletus luteus & topa mushroom Round head & shady areas & edible \\
\hline & M. vulgaris & morels & & edible \\
\hline & M. deliciosa & white morels & shady areas & edible \\
\hline & M. crassipes & Giant morels & shady areas & edible \\
\hline & Morchella esculenta & & shady areas & edible \\
\hline & Lentinus sajor-caju & Ring mushroom & shady areas & edible \\
\hline & Lentinus & & shady areas & edible \\
\hline \multirow{3}{*}{ Polyporaceae } & squarrosulus & Milky muahrooms & shady areas & edible \\
\hline & Lignosus sp. & & shady areas & edible \\
\hline & Panus lecomtei & Curry Mushroom & shady areas & edible \\
\hline \multirow{3}{*}{ Auriculariaceae } & Auricularia polythrica & monkey ear & shady areas & edible \\
\hline & Auricularia sp. 1 & Elephant ear & shady areas & edible \\
\hline & Auricularia auricular judae & Kulat Telinga & shady areas & edible \\
\hline \multirow{3}{*}{ Agaricaceae } & $\begin{array}{c}\text { Agaricus } \\
\text { subrutilescens }\end{array}$ & $\begin{array}{c}\text { Agaricus } \\
\text { subrutilescens }\end{array}$ & shady areas & Non edible \\
\hline & C.comatus & Not known & shady areas & Non edible \\
\hline & Agaricus sp. 1 & Not known & shady areas & Non edible \\
\hline \multirow{4}{*}{ Pleurotaceae } & Pleurotus giganteus & Not known & shady areas & Non edible \\
\hline & $\begin{array}{l}\text { Pleurotus tuber } \\
\text { regium }\end{array}$ & Not known & shady areas & Non edible \\
\hline & $\begin{array}{l}\text { Pleurotus djamor var. } \\
\text { djamor }\end{array}$ & Not known & shady areas & Non edible \\
\hline & Pleurotus ostreatus & Pata mushroom & shady areas & Non edible \\
\hline \multirow{2}{*}{ Marasmiaceae } & Marasmiellus sp. & Kulat sawit putih & shady areas & Non edible \\
\hline & Lentinula edodes & wild shitake & shady areas & Non edible \\
\hline Tremellaceae & Tremella fuciformis & $\begin{array}{l}\text { white } \\
\text { jelly }\end{array}$ & shady areas & Non edible \\
\hline Hygrophoraceae & Hygrocybe miniata & Kulat Top & shady areas & Non edible \\
\hline Pluteaceae & Volvariella volvacea & Paddy Straw mushroom & shady areas & Non edible \\
\hline Schizophyllaceae & $\begin{array}{c}\text { Schizophyllum } \\
\text { commune }\end{array}$ & Kulat Kodop & shady areas & Non edible \\
\hline Lyophyllaceae & Termitomyces eurrhizus & termite mushroom & shady areas & Non edible \\
\hline Cantharellaceae & $\begin{array}{l}\text { Chanterellus } \\
\text { cerinoalbus }\end{array}$ & Not known & shady areas & Non edible \\
\hline Calostomataceae & Calostoma insignis & Pig's eye mushroom & shady areas & Non edible \\
\hline
\end{tabular}




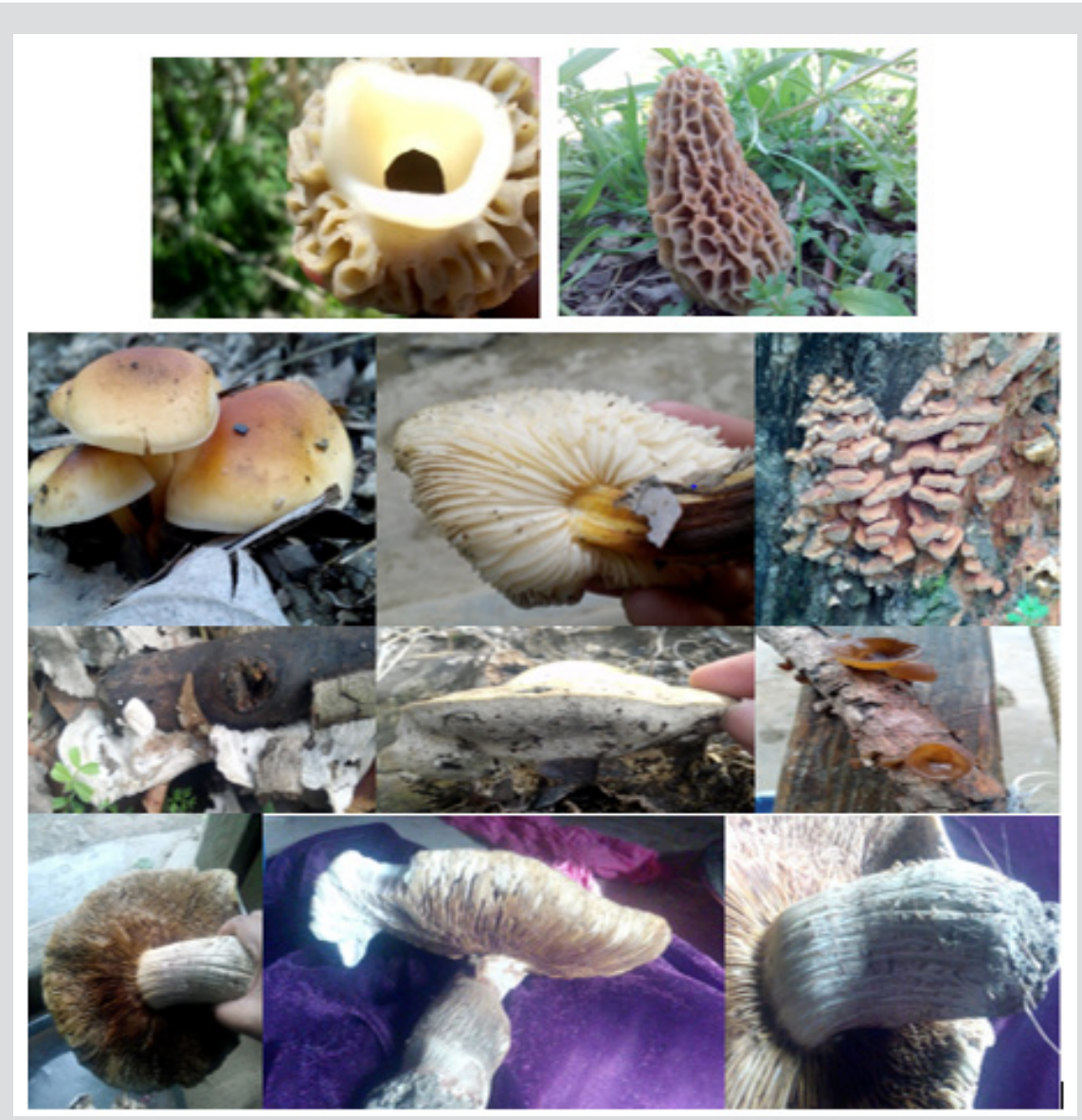

Figure 2: Some collected mushrooms from district Haripur.

\section{Discussion}

Knowledge on edible mushrooms is usually transferred from the older generation to the younger generation. Indigenous people living in the rural forest mainly use natural resources to sustain their subsistence [13]. Traditionally, older generations have vast knowledge on the uses of wild mushrooms. The younger generation only recognize the common edible wild mushrooms species. Currently, most of the younger generation have migrated to cities for job opportunities. Rural area have more forest coverage compared to urban areas. Previous studies have shown that depletion of ethno mycological knowledge may happen when people move to urban areas from rural villages [14]. Urbanization and land integration are two significant reasons that lead to the instant loss of their native knowledge from one generation to the next [15]. Similar results on these criteria in determining the edible mushrooms have been reported from other studies as well [16]. Several studies reported that Pleurotus species are valuable medicinal mushrooms [17]. In the Southeast Asia region, a diverse variety of wild mushroom have been found at local markets [18].

\section{Conclusion}

It is the first reported study from District Haripur. Local people were having very little knowledge on mushrooms. This will be helpful for the local community and researchers.

\section{Acknowledgment}

We would like to acknowledge the local community of villagers.

\section{References}

1. Miles PG, Chang ST (2004) Mushrooms: Cultivation, nutritional value, medicinal effect, and environmental impact, $\left(2^{\text {nd }}\right.$ edn.). 2004: CRC press, pp. 480.

2. Hyde KD, Bahkali AH, Moslem MA (2010) Fungi-An unusual source for cosmetics. Fungal diversity 43(1): 1-9.

3. Xu X, Yan H, Chen J, Zhang X (2011) Bioactive proteins from mushrooms. Biotechnol Adv 29(6): 667-674

4. Alananbeh KM, Bouqellah NA, Al Kaff NS (2014) Cultivation of oyster mushroom Pleurotus ostreatus on date-palm leaves mixed with other agro-wastes in Saudi Arabia. Saudi J Biol Sci 21(6): 616-625.

5. Simon Egli, François Ayer, Martina Peter, Britta Eilmann, Andreas Rigling (2010) Is forest mushroom productivity driven by tree growth? Results from a thinning experiment. Annals of forest science 67(5): 509-509.

6. Singh L, Fu CS, Rahman AA, Hameed WB, Sanmugam S, et al. (2015) Back to basics: A bilingual advantage in infant visual habituation. Child Dev 86(1): 294-302.

7. Clive G Jones, John H Lawton, Moshe Shachak (1994) Organisms as ecosystem engineers, in Ecosystem management. Springer 130-147.

8. James D Bever, Peggy A Schultz, Anne Pringle, Joseph B Morton (2001) Arbuscular mycorrhizal fungi: More diverse than meets the eye, and the ecological tale of why: The high diversity of ecologically distinct species of arbuscular mycorrhizal fungi within a single community has broad implications for plant ecology. Bioscience 51(11): 923-931. 
9. Beatrice Senn-Irlet, Jacob Heilmann-Clausen, David Genney, Anders Dahlberg (2007) Guidance for conservation of macrofungi in Europe. ECCF, Strasbourg, p. 1-38.

10. Bernuau J, Rueff B, Benhamou JP (1986) Fulminant and subfulminant liver failure: definitions and causes. Semin Liver Dis 6(2): 97-106.

11. Diaz JH (2005) Syndromic diagnosis and management of confirmed mushroom poisonings. Crit Care Med 33(2): 427-436.

12. McCormick DJ, Avbel AJ, Gibbons RB (1979) Nonlethal mushroom poisoning. Ann Intern Med 90(3): 332-335.

13. Wang YZ, Zhang J, Zhao YL, Li T, Shen T, et al. (2013) Mycology, cultivation, traditional uses, phytochemistry and pharmacology of Wolfiporia cocos (Schwein.) Ryvarden et Gilb.: a review. J Ethnopharmacol 147(2): 265276.

\section{ISSN: 2574-1241}

DOI: 10.26717/BJSTR.2019.18.003168

Saira Bibi. Biomed J Sci \& Tech Res

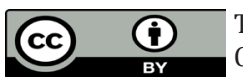

This work is licensed under Creative Commons Attribution 4.0 License

Submission Link: https://biomedres.us/submit-manuscript.php
14. Chelela BL, Chacha M, Matemu A (2014) Wild edible mushroom value chain for improved livelihoods in Southern Highlands of Tanzania. American Journal of Research Communication 2(8): 1-14.

15. Okhuoya J, Akpaja E, Osemwegie O, Oghenekaro A, Ihayere C (2010) Nigerian mushrooms: Underutilized non-wood forest resources. J Appl Sci Envir Manage 14(1).

16. Seifert KA (2009) Progress towards DNA barcoding of fungi. Mol Ecol Resour 9: 83-89.

17. Khan MA, Tania M, Liu R, Rahman MM (2013) Hericium erinaceus: An edible mushroom with medicinal values. J Complement Integr Med 10(1): 253-258.

18. Sanmee R, Dell B, Lumyong P, Izumori K, Lumyong S (2003) Nutritive value of popular wild edible mushrooms from northern Thailand. Food chemistry 82(4): 527-532.

BIOMEDICAL
RESEARCHES $\quad \begin{aligned} & \text { Assets of Publishing with us } \\ & \text { - }\end{aligned}$

